\title{
Effective chemical control of fruit flies (Diptera: Tephritidae) pests in mango orchards in northern Côte-d'Ivoire
}

\author{
Ossey Robert N'DEPO ${ }^{1,2^{*}}$, N'klo HALA ${ }^{1}$, Achille N'DA ADOPO ${ }^{1}$, Felix COULIBALY ${ }^{1}$, \\ Philippe Kouassi KOUASSI ${ }^{3}$, Jean-François VAYSSIERES ${ }^{4}$ et Marc DE MEYER ${ }^{5}$ \\ ${ }^{1}$ Centre National de Recherche Agronomique (CNRA), 01 BP 1740 Abidjan 01, Côte d'Ivoire. \\ ${ }^{2}$ Laboratoire de Biologie et Physiologie Animale, UFR Agroforesterie, \\ Université Jean-Lorougnon Guédé, Daloa, Côte d'Ivoire. \\ ${ }^{3}$ Laboratoire de Zoologie-Biologie Animale, UFR Biosciences-22 BP 582 Abidjan 22, Côte d'Ivoire. \\ ${ }^{4}$ Cirad, UPR Fruit Production, IITA Biological Control Center for Africa, \\ O8 BP 0932, Tri Postal, Cotonou, Benin. \\ ${ }^{5}$ Head Entomology Section Royal Museum for Central Africa Leuvensesteenweg 13 B-3080 Tervuren, Belgium. \\ "Corresponding author, E-mail: osseyndeporob@yahoo.fr
}

\begin{abstract}
Fruit flies are major pest in West Africa. In Côte-d'Ivoire, they caused heavy losses. Thus, preventive measures are taken to reduce their damage. The objective was to evaluate the effectiveness of Success Appat ${ }^{\circledR}$ and Proteus $170 O-T E Q$ against fruit. Traps baited with sexual attractants were set in mango orchards and their contents were collected each week. Bait and insecticide were renewed each month. Three orchards were treated with Success Appat ${ }^{\circledR}$ and three with Proteus 170 O-TEQ, respectively and their untreated orchards were selected. Mangoes were collected in treated and untreated orchards to assess the attack and infestation rates of orchards. Eight species of fruit flies were recorded. Bactrocera invadens was highly captured in different orchards. Orchards treated with Success Appat ${ }^{\circledR}$ have a lower rates of attack $(11.7 \pm 3.52 \%)$ and infection $(02.32 \pm 1.6$ pupae/ kg.f) than the untreated orchards, $(41.05 \pm 7.6 \%)$ and $(34.4 \pm 8.18$ pupae/ kg.f $)$, respectively. Equally, orchards treated with Proteus 170 O-TEQ showed lower rates of attack $(13.59 \pm 5.38 \%)$ and infection $(05.86 \pm 4.08$ pupae/ kg.f) than untreated $(47.37 \pm 10.95 \%)$ and $(44.72 \pm 15.64$ pupae/ kg.f), respectively. Insecticides Success Appat ${ }^{\circledR}$ and Proteus 170 O-TEQ significantly reduced the damage of fruit flies in orchards.
\end{abstract}

(C) 2015 International Formulae Group. All rights reserved.

Keywords: Fruit flies, mango orchards, chemical control.

\section{INTRODUCTION}

Fruits flies are major pest problem in West Africa, especially in Côte-d'Ivoire (Hala et al., 2006; N'dépo et al., 2009). These insects attack a wide range of fruit trees varieties, including citrus and berries (Mwatawala et al., 2004. Drew et al., 2005; Quilici et al., 2005 ;
Anonymous, 2006; Mwatawala et al., 2006; N'dépo, 2006; Quilici, 2007). These flies cause severe damage to fruit from 12 to $60 \%$ or even $80 \%$ of loss (Vayssières et al., 2005; N'dépo, 2010; N'dépo et al., 2010). Moreover, the economic loss is estimated to about $\$ 100$ million of $\$ 850$ million of an annual fruit 
production in Australia (White and ElsonHarris, 1992) and $€ 2.5$ million per year by Ceratitis capitata on fruit production in Madeira Island, South Africa (Dantas et al., 2002). Due to their enormous damage and their status of quarantine insects, fruit flies constitute major obstacle to the free movement of fresh vegetables in the world (Anon, 1994). Thus, preventive measures are developed and implemented to reduce the damage. Unfortunately, these measures are mostly out of reach of African farmers because of the expensive cost and lack of adequate infrastructure for their implementation. However, spot treatments with Success Appat $^{\circledR}$, frequently made in Reunion in citrus orchards, are being implemented in mango orchards in West Africa. Thus, in the context of "regional project against fruit flies in West Africa", the spot treatments with Success Appat ${ }^{\circledR}$ in mango orchards by Vayssières et al. (2009a), gave satisfactory results. This study consequently aimed at evaluating the effectiveness of Success Appat ${ }^{\circledR}$ and Proteus 170 O-TEQ in mango orchards by using the method of chemical control, to the approval of these products and to advise producers of fruits, flowers and vegetables in Côte-d'Ivoire.

\section{MATERIALS AND METHODS}

\section{Sites of study}

The study was conducted in the northern region of Côte-d'Ivoire; the main area of production of export mangoes. The climate is of Sudanese type, with an annual temperature of $25.5{ }^{\circ} \mathrm{C}$ and rainfall of 1100 $\mathrm{mm}$. Three different mango orchards from 1 to 3 hectares were treated with Success Appat $^{\circledR}$. The treated orchards were located in Napié $\left(09^{\circ} 17^{\prime} \mathrm{N}-05^{\circ} 35^{\prime} \mathrm{W}\right)$, Karakoro $\left(09^{\circ} 21 \mathrm{I}^{\prime} \mathrm{N}-05^{\circ} 32 \mathrm{~W}\right)$ and Waraniéré $\left(09^{\circ} 32^{\prime}\right.$ $\mathrm{N}-05^{\circ} 41 \mathrm{~W}$ ). As well, three other mango orchards treated with Proteus 170 O-TEQ were located in Napié $\left(09^{\circ} 16\right.$ 'N - $\left.05^{\circ} 34^{\prime} \mathrm{W}\right)$, Téguéré $\left(09^{\circ} 20 \quad\right.$ 'N $\left.-05^{\circ} 22^{\prime} \quad \mathrm{W}\right)$ and Nagbanakaha $\left(09^{\circ} 24\right.$ 'N - 05 $36^{\circ}$ W). For each treatment, one untreated mango orchard wider than 3 hectares was selected in each area. The distance separating the treated from the untreated orchards was more than $500 \mathrm{~m}$. This area was not covered by crop unsusceptible to chemical control such as cotton Gossypium hirsutum $\mathrm{L}$.

\section{Trapping of natural populations of fruit flies}

The dry Tephri and McPhail traps containing specific sexual attractants (methyl eugénol and terpinyl acetate) and an insecticide dichlorvos (DDVP), were laid out in the selected orchards. Each trap was labelled with the first letters of each lure. Attached on a branch of mango tree with a wire, the traps were suspended at about 1.60 to $1.80 \mathrm{~m}$ above ground to maximize the capture, away from sunlight and foliage to facilitate entrance of flies in traps. The traps' density was 2 traps per orchard separated with an optimal distance of $50 \mathrm{~m}$ (Vayssières et al., 2005; N'dépo et al., 2010; 2013). A total of 22 dry traps were used to cover the six orchards. The sexual attractants and insecticide were renewed every month. The different captures of the traps were separately collected every week. The collected insects were identified in the laboratory by using an identification guide (De Meyer, 2000; Ekesi and Billah, 2007).

\section{Insecticide application}

Phytosanitary treatments were applied when one of the three conditions is satisfied: the fruit ripening stage was reached (sensitive stage to fruit fly attack); one of the invasive fruit fly Bactrocera invadens was captured; or twenty Ceratitis cosyra were captured.

\section{Spots treatments with the Success Appat ${ }^{\circledR}$}

One liter of formulated product "Success Appat ${ }^{\circledR} "$ or "GF-120" [a.m: spinosad $(0.24 \mathrm{~g} / \mathrm{l})]$ was taken and dissolved in 51 of water (1:5 dilution) for 1 ha (Dow AgroSciences, 2001; Anonymous, 2008). Partial coverage treatment $\left(1 \mathrm{~m}^{2}\right.$ leaf area) was applied with a manual pressure sprayer SOLO 425 (capacity 15 l), rotationally around 
the tree, inside the canopy sheets avoiding fruits. All the trees of the field were treated and the application was renewed every week or after a heavy rain until the end of the fruit harvest. Each treated orchard (100 trees treated averagely) was a repetition.

Total treatment with the Proteus 170 OTEQ

Proteus $170 \quad$ O-TEQ (a.m: $20 \mathrm{~g} / \mathrm{l}$ deltamethrin and $150 \mathrm{~g} / \mathrm{l}$ thiacloprid) was applied at rate of $5 \mathrm{ml}$ per tree according to the recommendation of $500 \mathrm{ml} \mathrm{ha}^{-1} .40 \mathrm{ml}$ of the product were dissolved in 21 of water. The mixed liquid was supplemented with 121 of water and sprayed with the atomizer SOLO 423. The treatment was done by a homogeneous dispersion of the product in all parts of the tree with a high flow. The plots of large surface ( $\geq 1.5 \mathrm{ha}$ ) were subdivided into elementary fields. The trees of each elementary plot were treated with a frequency of 21 days. Each treated orchard (100 trees treated on average) was a repetition (N'Dépo, 2010).

Evaluation of the effectiveness of treatments

To evaluate the effectiveness of the products, the fruits were taken randomly from different treated and untreated plots separately. Infested fruits were identified and counted among picked fruit. The economic impact (ratio between the number of infested fruits and the total fruits collected per treatment), expressed as a percentage, was calculated using the formula below:

$$
\mathrm{IE}(\%)=(\mathrm{NFI} \times 100) / \mathrm{NFT}
$$

$\mathrm{IE}=$ economic impact, $\mathrm{NFI}=$ number of infested fruits, NFT= total fruits

\section{Statistical analysis}

Weekly average capture of fruit flies per orchard was subjected to analysis of variance (ANOVA) at the 5\% threshold. The averages are classified according to Tukey's test.

The rate of attack and infestation of treated and untreated orchards and abundance of each species in treated and untreated orchard were compared with Fisher t-Test using the STATISTICA V.7.1 software.

\section{RESULTS}

\section{Success Appat $^{\circledR}$ treatment and specific composition of fruit flies}

Eight species of fruit flies have been identified in treated orchards with Success Appat $^{\circledR}$ and untreated orchards. These included Bactrocera invadens, Ceratitis cosyra, Ceratitis bremii, Ceratitis punctata, Ceratitis anonae, Ceratitis rosa, Ceratitis ditissima and Trirhithrum coffeae. The invasive fly $B$. invadens was the most abundant species caught. The average capture was $186.48 \pm 37.95$ flies per week, $186.9 \pm$ 38.98 flies per week respectively in treated orchards and untreated orchards. The capture of other species fluctuates between 0.01 and 15.66 flies per week. The relative abundance of C. cosyra species with $7.35 \pm 1.95$ and $15.66 \pm 4.90$ individuals per week in treated and untreated orchards and $C$. bremii with $6.52 \pm 2.05$ and $4.43 \pm 1.27$ individuals per week in treated and untreated orchards was not statistically different. However, there was significant difference $(\mathrm{P}<0.05)$ between the abundances of $C$. rosa in untreated and treated (Table 1). The analysis of variance revealed a highly significant difference $(\mathrm{P}=0.000)$ between species abundance in the different orchards (Table 1). However, the comparison the abundance of flies in treated orchards with Success Appat ${ }^{\circledR}$ and untreated orchards is not statistically significant $(\mathrm{P}=0.95)$ (Table 1$)$.

\section{Proteus O-TEQ 170 treatment and specific composition of fruit flies}

Seven species of fruit flies have been identified in treated orchards with Proteus 170 $O-T E Q$ and untreated orchards. These were $B$. invadens, $C$. anonae, C. cosyra, C. bremii, $C$. 
rosa, C. punctata and C. capitata. Invasive species $B$. invadens was more abundant in orchards compared to other species. This average capture was $519.02 \pm 77.06$ individuals per week, $968.49 \pm 127.33$ individuals per week respectively in treated orchards and untreated orchards. The capture of other species fluctuates between 0.06 and 152.65 individuals per week. The analysis of variance revealed a highly significant difference between species abundance $(\mathrm{P}=$ 0.000) (Table 2).

At the treated and untreated orchards, statistical treatments reveal a significant difference in the abundance of $B$. invadens $(\mathrm{P}=0.003)$ (Table 2). It was the same for minority species $C$. cosyra and $C$. punctata whose abundance in untreated orchards and treated orchards was statistically different ( $\mathrm{P}<$ 0.01). Overall, the comparative study of the abundance of species of flies in treated and untreated plots revealed a high significant difference ( $\mathrm{P}=0.008$ ) (Table 2).

\section{Attack and infestation level with Success Appat $^{\circledR}$ treatment}

An important attack rate (economic impact) of fruits was observed during 2009 and 2010 in unsprayed orchards. Application of Success Appat ${ }^{\circledR}$ dropped dramatically the rate of attack. In fact, it was estimated to $11.70 \pm 3.52 \%$ in treated orchards against $41.05 \pm 7.60 \%$ in untreated orchards; about 3.5 times lower than the one of untreated orchards. The t-test detects a highly significant $(\mathrm{P}<0.01)$ difference between the attack rate in treated and untreated orchards (Table 3).

An important infestation rate also was recorded in treated orchards. In 2009, average of infestation rate was higher in untreated orchards with $25.68 \pm 6.4$ pupae $/ \mathrm{kg}$ of fruits than the one in treated orchards $(17.76 \pm 5.06$ pupae/kg of fruits). However, this difference was not statistically significant $(\mathrm{P}>0.05)$. In opposite, in 2010, the difference between the averages of infestation rate in untreated and treated orchards was statistically significant ( $\mathrm{P}$ $<0.01)$. Infestation rate was $2.33 \pm 1.60$ and $34.4 \pm 8.18$ pupae $/ \mathrm{kg}$ of fruits respectively in treated and untreated orchards, representing about 14.7 times the infestation rate average of treated orchards (Table 3).

\section{Attack and infestation level with Proteus 170 O-TEQ treatment}

The attack level of treated orchards with Proteus 170 O-TEQ during 2009 and 2010 was significantly lower than the one in untreated orchards. In 2010, the average rate in untreated orchards was estimated to $47.37 \pm$ $10.95 \%$ representing about 3.41 times the infestation rate in treated orchards which was $13.59 \pm 5.38 \%$. Generally, the attack rate was estimated to $8.82 \pm 3.61 \%$ in treated orchards and $33.28 \pm 7.88 \%$ in untreated orchards. The statistical analysis gave a highly significant $(\mathrm{P}$ $<0.01)$ difference between the attack level in the orchards (Table IV). Important variation was observed on infestation rates of orchards. The infestation load of treated fruits with Proteus $170 \quad O-T E Q$ was $13.92 \pm 10.25$ pupae $/ \mathrm{kg}$ of fruits and $5.86 \pm 4.08$ pupae $/ \mathrm{kg}$ of fruits respectively in 2009 and 2010. In untreated orchards, the infestation load was $98.67 \pm 23.3$ pupae $/ \mathrm{kg}$ of fruits and $44.72 \pm$ 15.64 pupae/kg of fruits in 2009 and 2010, respectively. Thus, the infestation load in untreated orchards was more than 7 times the one of treated orchards. Statistical analysis showed a highly significant $(\mathrm{P}<0.01)$ difference between infestation loads in treated and untreated orchards (Table 4). 
Table 1: Effect of Success Appat ${ }^{\circledR}$ treatment on average capture of fruit flies in mango's orchards.

\begin{tabular}{lccc}
\hline Species & Treated orchards (SA) & Untreated orchards & Probability \\
\hline B. invadens & $186.48 \pm 37.95^{\mathbf{b}}$ & $187.9 \pm 38.98^{\mathbf{b}}$ & $\mathrm{P}=0.98$ \\
C. anonae & $0 \pm 0.0^{\mathrm{a}}$ & $0.03 \pm 0.02^{\mathrm{a}}$ & $\mathrm{P}=0.16$ \\
C. bremii & $6.52 \pm 0.4^{\mathrm{a}}$ & $4.43 \pm 1.27^{\mathrm{a}}$ & $\mathrm{P}=0.39$ \\
C. cosyra & $7.35 \pm 1.95^{\mathrm{a}}$ & $15.66 \pm 4.9^{\mathrm{a}}$ & $\mathrm{P}=0.12$ \\
C. ditissima & $0.01 \pm 0.01^{\mathrm{a}}$ & $0.01 \pm 0.01^{\mathrm{a}}$ & $\mathrm{P}=1$ \\
C. punctata & $0.03 \pm 0.02^{\mathrm{a}}$ & $0.03 \pm 0.02^{\mathrm{a}}$ & $\mathrm{P}=1$ \\
C. rosa & $0.03 \pm 0.02^{\mathrm{a}} *$ & $0.22 \pm 0.07^{\mathbf{b} *}$ & $\mathbf{P}=\mathbf{0 . 0 2}$ \\
T. coffeae & $0.01 \pm 0.01^{\mathrm{a}}$ & $0 \pm 0.0^{\mathbf{a}}$ & $\mathrm{P}=0.31$
\end{tabular}

\begin{tabular}{lcc}
\hline Probability $(\mathbf{P})$ & $\mathbf{P}=\mathbf{0 . 0 0 0 0}$ & $\mathbf{P}=\mathbf{0 . 0 0 0 0}$ \\
\hline Fisher t-Test & & $\mathrm{P}=0.95$ \\
\hline
\end{tabular}

SA: Success Appat $\left.{ }^{\circledast},{ }^{*}\right): \mathrm{P}<0.05$.

ANOVA at $5 \%$, means in column followed by the same letter are not significantly different.

Fisher t-Test $5 \%$, means in row followed by the asterix are significantly different.

Table 2: Effect of Proteus 170 O-TEQ treatment on average capture of fruit flies in mango's orchards.

\begin{tabular}{lccc}
\hline Species & Treated orchards (PRO) & Untreated orchards & Probability \\
\hline B. invadens & $514.02 \pm 77.06^{\mathbf{a} * *}$ & $968.49 \pm 127.3^{\mathbf{b}_{* * *}}$ & $\mathbf{P}=\mathbf{0 . 0 0 3}$ \\
C. anonae & $0 \pm 0.0^{\mathbf{a}}$ & $0.1 \pm 0,07^{\mathbf{a}}$ & $\mathrm{P}=0.16$ \\
C. bremii & $4.14 \pm 1.31^{\mathbf{a}}$ & $4.83 \pm 1.14^{\mathbf{a}}$ & $\mathrm{P}=0.69$ \\
C. cosyra & $29.12 \pm 6.09^{\mathbf{a} * *}$ & $152.65 \pm 35.01^{\mathbf{b}_{* *}}$ & $\mathbf{P}=\mathbf{0 . 0 0 1}$ \\
C. capitata & $0 \pm 0.0^{\mathbf{a}}$ & $0.06 \pm 0.06^{\mathbf{a}}$ & $\mathrm{P}=0.33$ \\
C. punctata & $0 \pm 0.0^{\mathbf{a} *}$ & $0.64 \pm 0.27^{\mathbf{b} *}$ & $\mathbf{P}=\mathbf{0 . 0 2}$ \\
C. rosa & $0.06 \pm 0.06^{\mathbf{a}}$ & $0.1 \pm 0.07^{\mathbf{a}}$ & $\mathrm{P}=0.66$ \\
\hline Probability & $\mathbf{P}=\mathbf{0 . 0 0 0 0}$ & $\mathbf{P}=\mathbf{0 . 0 0 0 0}$ & \\
\hline Fisher t-Test & & $\mathrm{P}=0.008$ & \\
\hline
\end{tabular}

PRO: Proteus 170 O-TEQ ; (**): P < 0.01; $\left(^{*}\right): \mathrm{P}<0.05$; ANOVA at $5 \%$, means in column followed by the same letter are not significantly different; Fisher t-Test at $5 \%$, means in row followed by the asterix are significantly different.

Table 3: Attack and infestation rates of mango's orchards treated with with Success Appat ${ }^{\circledR}$.

\begin{tabular}{lcccccc}
\hline Treatment & \multicolumn{5}{c}{ Attack rate (\%) } & \multicolumn{5}{c}{ Years } \\
\cline { 2 - 7 } & \multicolumn{7}{c}{ Averation rate (pupae/kg fruits) } \\
\cline { 2 - 7 } & $\mathbf{2 0 0 9}$ & $\mathbf{2 0 1 0}$ & $\mathbf{2 0 0 9}$ & $\mathbf{2 0 1 0}$ & Average \\
\hline PSA & $16.01 \pm 6.69^{\mathrm{a}}$ & $8 \pm 3.03^{\mathrm{a}}$ & $11.7 \pm 3.52^{\mathrm{a}}$ & $17.76 \pm 5.06^{\mathrm{a}}$ & $2.33 \pm 1,6^{\mathrm{a}}$ & $9.45 \pm 3,25^{\mathrm{a}}$ \\
Control plots & $24.92 \pm 10.05^{\mathrm{a}}$ & $54.87 \pm 8.35^{\mathrm{b}}$ & $41.05 \pm 7.6^{\mathrm{b}}$ & $25.68 \pm 6.4^{\mathrm{a}}$ & $34.4 \pm 8.18^{\mathrm{b}}$ & $30.38 \pm 5.25^{\mathrm{b}}$ \\
Probability & $\mathrm{P}=0.48$ & $\mathrm{P}=0.000$ & $\mathrm{P}=0.002$ & $\mathrm{P}=0.36$ & $\mathrm{P}=0.002$ & $\mathrm{P}=0.002$ \\
\hline
\end{tabular}

PSA : Treated plots with Success Appat ${ }^{\circledR}$; Means affected by the same letter in column are not significantly different. 
Table 4: Attacks and infestation Rates of mango's orchards treated with Proteus 170 O-TEQ.

\begin{tabular}{lcccccc}
\hline Treatment & \multicolumn{3}{c}{ Attack rate (\%) } & \multicolumn{3}{c}{ Years } \\
\cline { 2 - 6 } & \multicolumn{5}{c}{ Infestation rate (pupae/kg fruits) } \\
\cline { 2 - 6 } & $\mathbf{2 0 0 9}$ & $\mathbf{2 0 1 0}$ & Average & $\mathbf{2 0 0 9}$ & $\mathbf{2 0 1 0}$ & Average \\
\hline PPRO & $4.83 \pm 4.64 \mathrm{a}$ & $13.59 \pm 5.38 \mathrm{a}$ & $8.82 \pm 3.61 \mathrm{a}$ & $13.92 \pm 10.25 \mathrm{a}$ & $5.86 \pm 4.08 \mathrm{a}$ & $10.26 \pm 5.77 \mathrm{a}$ \\
Control plots & $21.53 \pm 9.33 \mathrm{~b}$ & $47.37 \pm 10.95 \mathrm{~b}$ & $33.28 \pm 7.88 \mathrm{~b}$ & $98.67 \pm 23.3 \mathrm{~b}$ & $44.72 \pm 15.64 \mathrm{~b}$ & $74.15 \pm 16.27 \mathrm{~b}$ \\
Probability & $\mathrm{P}=0.14$ & $\mathrm{P}=0.02$ & $\mathrm{P}=0.01$ & $\mathrm{P}=0.008$ & $\mathrm{P}=0.04$ & $\mathrm{P}=0.001$ \\
\hline \multicolumn{2}{c}{ PPRO : Treated plots to Proteus 170 O-TEQ; } \\
\multicolumn{2}{c}{ Means affected by the same letter in column are not significantly different. }
\end{tabular}

\section{DISCUSSION}

Fruit flies associated with mango such as Bactrocera invadens, Ceratitis cosyra, Ceratitis bremii were present in varied proportions in orchards under insecticide control (Proteus 170 O-TEQ and Success Appat $^{\circledR}$ ) and unsprayed orchards. The early appearance of $C$. cosyra species from midMarch corresponds to the period of full maturity of mango variety Amelie (Vayssières et al., 2005, 2008, 2009b,c). Its appearance is shortly followed by the emergence and proliferation of the semi-late species $B$. invadens (N'dépo et al., 2009, 2013). The latter species exert a strong parasite pressure on other native species, which could be the reason of its important presence in mango orchards, particularly in mangoes. In treated and untreated orchards, the species Bactrocera invadens remained the major species with significantly higher population than that of others species, especially that of Ceratitis cosyra, formerly major in orchards (Hala, 2001). The high proportion of Bactrocera invadens in treated orchards, can be explained on one hand, by a high invasion of orchards, followed by a high emergence rate of flies from pupae and, on other hand, by the late application of insecticides (early April) in too infested orchards by fruit flies. The low proportion of other species (minor species) in treated orchards could be due in addition to the intense interspecific competition between $B$. invadens and those latest (Duyck et al., 2004. 2006 and 2007), their sensitivity to insecticides. In fact, according Evdoxia et al. (2009), Spinosad is a new insecticide derived from a soil bacterium Saccharopolyspora spinosa Mertz \& Yao, which is effective against a wide range of insects, including the olive fly Bactrocera oleae Rossi. According to these authors, this new generation of insecticides acts by ingestion or contact with insects, specifically at a site of nicotinic acetylcholine receptor firstly and secondly in the GammaAminobutyric acid (GABA). Thus, it greatly reduces the attack rate of mangoes and consequently, the infestation rate of fruits in treated orchards through the death of poisoned fruit flies (Dow AgroSciences, 2008). Although the level attack and infestation of orchards treated with Success Appat ${ }^{\circledR}$ was low in 2009, this was not statistically significant. These results are close to those of Vayssières et al. (2009a) who applied Success Appat ${ }^{\circledR}$ and revealed a highly significant difference between the damage reduction rate of untreated and treated orchards in 2006 and 2007 in Benin. It is explained by a wrong manipulation of insecticide produced during the test plots. In terms of productivity, the treated orchards with Success Appat ${ }^{\circledR}$ were higher than that of untreated orchards yield (N'dépo, 2010). Application of Proteus 170 $O-T E Q$ significantly reduces the attack and fruit infestation rate in mango orchards. This new generation of insecticide with two complementary active ingredients deltamethrin $(20 \mathrm{~g} / \mathrm{l})$ and thiacloprid $(150 \mathrm{~g} / \mathrm{l})$ 
is recognized for its effectiveness in the control of a large number of pests (Anonymous, 2009a). It reduces the rate of damage caused to the mango just like Success Appat $^{\circledR}$. As demonstrated, both products reduced the damage caused by fruit flies in orchards and are effective against fruit flies (Anonymous, 2009b).

\section{Conclusion}

Eight species of fruit flies have been identified in mango orchards. Among these pests, the species $B$. invadens and $C$. cosyra are most abundant in northern of Côted'Ivoire with a large proportion of invasive fly. The attack and infestation rate in orchards sprayed with Success Appat ${ }^{\circledR}$ and Proteus 170 $O-T E Q$ were significantly lower than those of untreated orchards. These products have significantly reduced the attacks rate in treated orchards. Products Proteus 170 O-TEQ (dose: $0.51 \mathrm{ha}^{-1}$ ) and Success Appat ${ }^{\circledR}$ (dose: $11 \mathrm{ha}^{-1}$ ) were effective in the control of fruit flies and improved production yield.

\section{ACKNOWLEDGEMENTS}

We thank the World Bank for funding the project "Regional project of control against fruit flies in West Africa". Our thanks also go to IITA for work equipment supply. Finally, our sincere thanks to all the actors in the mango industry for their cooperation. We also thank Clément Odon N'CHO for his assistance in translating the manuscript into english.

\section{REFERENCES}

Anonymous. 2006. Bactrocera invadens (Diptera: Tephritidae) a new fruit fly species. Newsletter, p. 2. (EPPO: European and Mediterranean Plant Protection Organisation). http://www. eppo.org// le 14 février 2006.

Anonymous. 2008. True fruit flies (Diptera : Tephritidae) of the Afrotopicale region. http://www.projects.bebif.be//fruitfly/taxo ninfo.htm/, modifié 16 mars 2010.

Anonymous. 2009a. Nouvel insecticide Proteus $^{\circledR}$ s'attaque aux ravageurs récalcitrants. http://www.terre-net.fr/, le 18 septembre 2009.

Anonymous. 2009b. Bayer Crop Sciences lance Proteus $\AA$, une solution innovante contre les ravageurs difficiles à maîtriser. Communiqué de presse, http://www. bayercropscience.fr/, Lyon, France, le 11 septembre 2009, p. 2.

Dantas L, Pereira R, Silva N, Rodrigues A, Costa R. 2002. The SIT control programm against Medfly on Madeira Island. Proceedings of the 6 th International Symposium on fruit flies of economic importance, Brian N. B., Ed, Stellenbosch, South Africa, p. 510.

De Meyer M. 2000. Systematic revision of the subgenus Ceratitis Macleay s.s. (Diptera: Tephritidae). Zoological Journal of Linnean Society, 128: 439-467.

Dow AgroSciences. 2001. Spinosad Technical Bulletin. Dow AgroSciences LLC: Indianapolis, IN; 3.

Dow AgroSciences. 2008. Syneïs appât et Succes 4: lutte contre la mouches du brou du noyer. Notice technique. http://www.dowagro.com/fr/succes 4, le 07 mai 2008.

Drew RAI, Tsuruta K, White IM. 2005. A new species of pest fruit fly (Diptera: Tephritidae: Dacinae) from Sri Lanka and Africa. African Entomology, 13(1): 149154.

Duyck PF, David P, Quilici S. 2004. A review of relationships between interspecific competition and invasions in fruit flies (Diptera: Tephritidae). Ecological Entomology, 29: 511-520.

Duyck PF, David P, Quilici S. 2006. Climatic nichepartitioning following successive invasions by fruit flies in La Réunion. Journal of Animal Ecology, 75: 518-526. 
Duyck PF, David P, Quilici S. 2007. Can more K-selected species be better invader? A case study of fruit flies in $\mathrm{La}$ Réunion. Diversity and Distrbitions (Diversity Distrib.), 13: 535-543.

Ekesi S, Billah MK. 2007. Afield Guide to the Management of Economically Important Tephritid Fruit Flies in Africa $\left(2^{\text {nd }}\right.$ edn). ICIPE Science Press: Nairobi, Kenya; 34.

Evdoxia GK, Nikos EZ, Konstantina TT, Nios S, Frank GZ, Kostas DM. 2009. Spinosad resistance development in wild olive fruit fly Bactrocera oleae (Diptera: Tephritidae) populations in California. Society of Chemical Industry, (www.interscience.wiley.com) DOI 10.1002/ps.1921, p. 7.

Hala NF. 2001. Lutte contre les mouches des fruits. Convention CNRA/ ICIPE, Rapport d'exécution technique 2000, CNRA, p. 11.

Hala NF, Quilici S, Gnago AJ, N'dépo OR, Kouassi KP, Allou KR. 2006. Status of fruit flies (Diptera: Tephritidae) in Côted'Ivoire and implications for mango exports. Proceeding of $7^{\text {th }}$ International Symposium on Fruit Flies of Economic Importance, Sept. 10- 15, 2006, Salvadore, Bahia, Brazil, p 233-239.

Mwatawala MW, De Meyer M, Makundi R. H, Maerere PA. 2006. Biodivresity of fruit flies (Diptera: Tephritidae) in orchards in different agro-écological zones of the Morogoro, Tanzania. Fruits, 61(5): 321-332.

Mwatawala MW, White IM, Maerere AP, Senkondo FJ, De Meyer M. 2004. A new invasive Bactrocera species (Diptera: Tephritidae) in Tanzania. African Entomology, 12(1): 154-156.

N'dépo OR. 2006. Inventaire des mouches des fruits (Diptera: Tephritidae) dans les stations expérimentales d'Azaguié et de Yamoussoukro (Côte-d'Ivoire). Mémoire
D.E.A d'Entomologie Générale, Université de Cocody Abidjan (RCI), p. 59.

N'dépo OR. 2010. Biologie et écologie de Bactrocera invadens Drew, Tsuruta et White, 2005 (Diptera: Tephritidae), principal déprédateur des vergers fruitiers en Côte-d'Ivoire: possibilité de lutte chimique raisonnée contre les mouches des fruits. Thèse de Doctorat, Université de Cocody-Abidjan, p. 177.

N'dépo O R, Hala NF, Allou K, Aboua LR, Kouassi KP, Vayssières JF, De Meyer M. 2009. Abondance des mouches des fruits dans les zones de production fruitière de Côte-d'Ivoire : dynamique des populations de Bactrocera invadens (Diptera: Tephritidae). Fruits, 64(5): 313-324.

N'dépo OR, Hala NF, Gnago A, Allou K, Kouassi KP, Vayssières JF, De Meyer M. 2010. Inventaire des mouches des fruits de trois régions Agro-écologiques et plantes-hôtes associées à l'espèce nouvelle Bactrocera (Bactrocera) invadens Drew et al. (Dptera: Tephritidae) en Côte-d'Ivoire. European Journal of Scientific Research, 46(1) : 6372.

N'dépo OR, Hala N'K, N'da Adopo A, Coulibaly F, Kouassi Kouassi P, JeanFrançois V, De Meyer M. 2013. Fruit flies (Diptera: Tephritidae) populations dynamic in mangoes production zone of Côte-d'Ivoire. Agricultural Science Research Journal, 3(11): 352- 363.

Quilici S. 2007. La mouche des fruits Bactrocera invadens. Fiche technique programme régional des protections des végétaux. CIRAD, p. 4. http://www. prpv.org//. Le 16/04/2007.

Quilici S, Duyck PF, Rousse P, Courdon F, Simiand C, Franck A. 2005. La mouche de la pêche sur mangue, goyave etc. 
Phytoma. La Défense des Végétaux, 584: 44-47.

Vayssières JF, Georg G, Orphée L, Dossa P, Akponon C. 2005. A new Bactrocera species in Benin among mango fruit fly (Diptera: Tephritidae) species. Fruits, 60(6): 371-377.

Vayssières JF, Korie S, Ayegnon D. 2009c. Correlation of fruit fly (Diptera: Tephritidae) infestation of major mango cultivars in Borgou (Benin) with abiotic and biotic factors and assessment of damage. Crop Protection, 28: 477-488.

Vayssières JF, Korie S, Coulibaly $\mathrm{O}$, Cathelijne VM, Temple L, Djalal A, 2009b. The mango tree in central and northern Benin: damage caused by fruit flies (Diptera: Tephritidae) and computation of economic injury level. Fruits, 64(4): 207-220.

Vayssières JF, Sinzogan AAC, Van PM, 2008. Utilisation des fourmis tisserands (Hymenoptera : Formicidae) dans la lutte contre les mouches des fruits (Diptera: Tephritidae). «Projet régional de lutte contre es mouches de sfruits en Afrique de l'ouest», IITA-CIRAD. Fiche technique $\mathrm{N}^{\circ} 5$, p. 4.

Vayssières JF, Sinzogan A, Korie S, Ouagoussounon I, Odjo AT. 2009a. Effectiveness of spinosad bait sprays (GF-120) in controlling mango-infesting fruit flies (Diptera: Tephritidae) in Benin. Journal of Economic Entomology, 102(2): 515-521. 